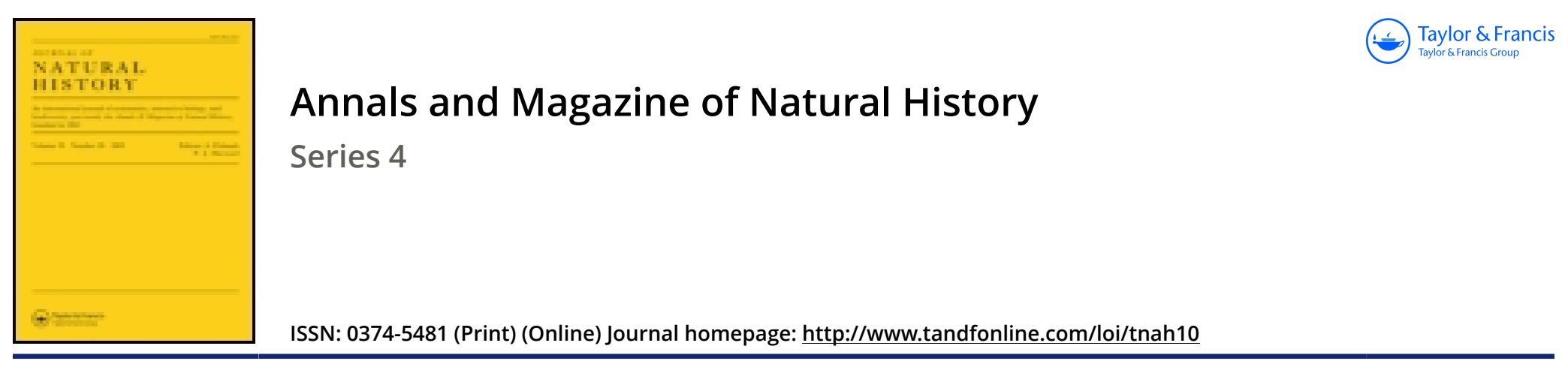

\title{
XXII.-Descriptions of two new species pertaining to the Avifauna of Australia
}

\author{
John Gould F.R.S.
}

To cite this article: John Gould F.R.S. (1871) XXII._Descriptions of two new species pertaining to the Avifauna of Australia , Annals and Magazine of Natural History, 8:45, 192-193, DOI: 10.1080/00222937108696464

To link to this article: http://dx.doi.org/10.1080/00222937108696464

曲 Published online: 16 Oct 2009.

Submit your article to this journal $\sqsubset \pi$

Џ Article views: 3

Q View related articles $\sqsubset$ 
varied forms of bill : compare the short bill of the Ramphomicron, one-third of an inch, and the six-inch bill of the Docimastes - the bill of the Eutoxeres, bent down into a semicircle, and that of the Avocettula, turning upwards. To an unequalled splendour of plumage (resembling laminæ of topaz and emerald) Nature has not added the gift of song. Their ordinary cry is a shrill chirik, uttered by the males in their petty quarrels. The "warbles" ascribed to the Mellisuga and Oreotrochilus need to be heard again to be credited.

XXII.-Descriptions of two new Species pertaining to the Avifauna of Australia. By JoHN GouLd, F.R.S. \&c.

HAving lately received from my friend F. G.Waterhouse, Esq., by permission of the Directors of the South-Australian Institute at Adelaide, a small collection of birds for identification, I find among them two previously unknown, descriptions of which I hasten to communicate to the scientific world. The first is of especial interest, inasmuch as it is a second species of the genus Xerophila, of which only one was previously known; and the second is an additional member of that elegant group of little Terns the Sternula.

\section{Xerophila pectoralis, Gould.}

Face and throat white, passing into greyish white on the earcoverts; crown and nape hair-brown mottled with blackish brown, the darker tint occupying the centre of each feather; back chestnut-brown, becoming much darker and richer on the rump; upper tail-coverts hair-brown; two central tailfeathers hair-brown, with lighter edges; the five lateral feathers on each side black tipped with white; across the chest a well-defined band of cinnamon-brown; under surface white, with a mark of chestnut down the centre of each of the flank-feathers; wings dark brown, the secondaries broadly margined with dull buff; under tail-coverts buffy white; bill and feet black.

Total length $3 \frac{7}{8}$ inches; bill $\frac{3}{8}$, wing $2 \frac{1}{4}$, tail $1 \frac{5}{8}$, tarsi $\frac{5}{8}$.

Hab. Port Augusta, South Australia.

Remark. This highly curious form reminds one of Ephthianur $\alpha$, but is distinguished from it by the bill being almost as thick as that of a finch.

\section{Sternula placens, Gould.}

Adult male. Bill yellow, with the apical third of both mandibles black, as sharply defined as if they had been dipped in 
ink; forehead white, advancing over each eye to near its posterior angle; lores, a narrow line above the eyes, crown and nape black; upper surface of the body and wingcoverts grey; the first primary slaty black on the outer web and along the inner web next the shaft; the shaft itself and the outer half of the inner web white; the second primary similarly but a little less strongly marked; the remainder of the primaries silvexy grey, with lighter shafts; throat and all the under surface of the body silky white; tail white; feet yellow.

Total length 10 inches; bill, from the gape, $1 \frac{5}{8}$, wing $7 \frac{1}{2}$, tail $4 \frac{3}{8}$, tarsi $\frac{3}{4}$. $H a b$. Torres Straits.

Remark. Two specimens of this bird are now before me:one, a female, which has been in my collection for many years; the other, a fine adult male, forming part of the collection above mentioned, and which had lately been received at Adelaide from the northern territory at Port Darwin.

I have carefully compared this species with the Sternula nereis of Australia, the S. minuta of Europe, and the Sternula of India, supposed to be identical with the latter (but this, I think, is a question). I have also compared it with all the little Terns of America, both North and South. Its nearest ally seems to be the European species; but from this it differs in having considerably longer wings, in the snow-white hue of the shafts of the primaries, and in the larger and welldefined mark of black on the tips of the mandibles; from $S$. nereis it is distinguished by having black instead of white lores.

\section{XXIII.-Whence comes the Nourishment for the Animals of} the Deep Seas? By Prof. Karu MöBIUs*.

The investigations of the greatest depths of the ocean, made in Baffin's Bay by John Ross (1818), in the Pacific Ocean by James Ross (1843), in the North-Atlantic Ocean by Wallich (1860), near Spitzbergen by Chydenius and Torell (1861), in the north-eastern part of the Atlantic by Carpenter, Jeffreys, and Thomson (1868 and 1869), and in the Gulf-stream off Florida by Pourtales (1869), have shown that the bottom of the ocean at great depths (550-3000 fathoms) consists princi-

* Translated by W.S. Dallas, F.L.S., from a separate copy of the paper sent by the author to Dr. J. E. Gray, F.R.S.

Ann. \& Mag. N. Hist. Ser. 4. Vol. viii. 